\title{
What Do Students Want? Making Sense of Student Preferences in Technology-enhanced Learning
}

\author{
Ekaterina Pechenkina \& Carol Aeschliman \\ Swinburne University of Technology, Australia
}

\begin{abstract}
This article, with its focus on university students as intended recipients and users of technological innovations in education, explores student preferences across three dimensions of technology-enhanced learning: mode of instruction; communication; and educational technology tools embedded in learning and teaching activities. The article draws on results of an exploratory case study, where mixed (quantitative and qualitative) data was collected from a randomized student sample generated through the institutional learning management system. An online survey $(\mathrm{N}=66)$ gaged students' engagement with educational technologies, online and blended learning and social media as a learning tool. The findings confirmed previous research arguing that students generally use educational technology in a narrow way, rarely engaging with technological tools, unless it is presented to them as integral to their learning or if they are already familiar with a particular tool and/or perceive it as useful. Despite a well-cited characteristic by proponents of 'digital natives' that students need constant entertainment, this study found no evidence that this was the case.
\end{abstract}

Keywords: Educational Technology; Student Preferences; Blended Learning; Social Media

\section{Introduction}

Technology-enhanced teaching and learning models have now become the 'new normal' in Higher Education (HE). Driven in part by student demand for individualized learning (Johnson, Adams Becker, Estrada, \& Freeman, 2015) and in part by universities' aspirations to be seen as innovative and in sync with the latest trends in educational technologies (Kukulska-Hulme, 2012), various technologies are introduced in and out of the classroom. Studying student experiences and engagement patterns within technology-enhanced education therefore emerges as central to our understanding of what works and what does not. While this topic received some attention in recent $\mathrm{HE}$ studies, further investigations are needed to better understand these experiences and generate practical recommendations.

Located within the wider HE context of technology-enhanced learning and teaching, the focus of this article is on university students as intended users of technological innovation in education. Building on the evidence-based research into what students prefer and expect when it comes to educational technologies, how they engage with new educational offerings and what their experiences with technology-enhanced education mean in terms of their academic performance and retention, the article reports on students' experiences with three dimensions of technology-enhanced education: 
- Students' preferences for a mode of teaching and learning delivery (that is, blended, fully-online or face-to-face);

- Students' preferences for social media used as a learning tool; and

- Students' preferences for educational technologies.

This research ( $\mathrm{N}=66)$ was an exploratory case study, where mixed (quantitative and qualitative) data was collected from a randomized student sample generated through the institutional Learning Management System (LMS) based on student enrolments in the second half of 2014.

\section{Aims of the Study}

The use of technology in education is often described with much passion and hyperbole (Henderson, Selwyn, Finger, \& Aston, 2015) and many of the subsequent myths that surround this rhetoric are promulgated by academics and students alike. One of the issues of most concern with this approach are the underlying presumptions that not only is learning taking place with technology, but also that it is actually being driven by technology (Selwyn, 2016). The principal aim of this study is to challenge one of these presumptions, that is the misconception that students demand advanced technology from their teachers (Prensky, 2001b) and that, as 'digital natives' they are of a different mindset to older generations and so use digital tools in highly innovative and creative ways (Bauerlein, 2008). The second aim is to determine which technological tools are most used by students and the final aim is to examine the ways in which students actually use technology in their academic lives.

\section{University Students and Technology}

A significant portion of the academic discourse surrounding students' needs for and engagement with innovative technology-enhanced education is still influenced by the controversial concept of 'digital natives' (Prensky, 2001b) proposing that younger people exhibit distinctive sets of behaviors which are productive for learning, such as a preference for speed, nonlinear processing and social learning (Rideout, Foehr, \& Roberts, 2010), collaboration (Rosen \& BeckHill, 2012; Tapscott, 2009), multitasking (Teo, 2013), and importantly, that they have an innate ability to harness technological knowledge and skills for learning (Gurung \& Rutledge, 2014) as well as possess well-developed visual-spatial skills (Prensky, 2001a; Tapscott, 2009). Other studies, however, suggest that digital natives' saturation in technology may actually impede their learning, as these students may lack ability for deep learning and hence exhibit decreased productivity (Bauerlein, 2008; Small \& Vorgan, 2008) and over-emphasize socialization rather than learning (Bauerlein, 2008). In any case, there are still those who argue that educators are failing to provide these digital natives with the technology-rich teaching environment in which they have been always immersed, and which they apparently need (Bauerlein, 2008; Rideout et al., 2010; Rosen \& Beck-Hill, 2012).

Recent studies challenge many of the key assumptions underpinning Prensky's (2001b) characterization of the digital native showing that age is not a determining factor in why some people espouse technology while others avoid it (Helsper \& Eynon, 2010; Kennedy, Judd, Churchward, Gray, \& Krause, 2008). In fact, there are studies showing how reluctant students 
are to engage with technology (Thompson, 2013), disputing the assumption that younger learners are proficient with technology and, therefore, should be challenged with technology (Ferdig \& Trammell, 2004). Furthermore, Thompson (2013) draws on studies from Australia (Kennedy, Dalgarno, et al., 2008; Kennedy, Judd, et al., 2008), Canada (Guo, Cheung, \& Tan, 2008), and the United Kingdom (Jones, Ramanau, Cross, \& Healing, 2010) to demonstrate how their findings are consistent with hers; while similar conclusions are also drawn by Margaryan, Litttlejohn and Vojt (2011). Finally, Kennedy, Judd, Dalgarno and Waycott, (2008) make an relevant observation that most digital natives use technology solely for communication, rather than in innovative and creative ways.

A variety of diverse factors play a role in how students interact with educational technologies. Digital literacy - both the self-perception of one's proficiency by students and their actual digital literacy skills - is one of them. For example, a study assessing incoming first-year university students' "functional computer literacy" (Hoffman \& Vance, 2005, p. 356), found that "students learn what they want to learn, and generally learn what they want to know informally". In particular, the tasks on which students ranked their skills highest were those they were most likely to engage in anyway, regardless of educational contexts, such as e-mail and instant messaging, and in which they had mostly learnt the necessary skills themselves (Hoffman \& Vance, 2005, p. 359). Another study (Kennedy, Judd, et al., 2008) demonstrated that while students were overwhelmingly positive about the use of ICT to support their studies, technologies like blogs, file sharing, social networks, and web-conferencing were embraced by a smaller proportion of students. Overall, it can be difficult to separate nature and complexity of students' use; as one can be determined by the other while students' perception of their own technology usage mastery is not always reflective of their actual skills (Kvavik, 2005). From this complex field of knowledge, three areas of particular interest emerge: students' perception of various modes of learning, their use of social media platforms in educational contexts and their experience with educational technology tools more broadly, all of which are considered next.

\section{Teaching and Learning Delivery Modes}

A mode of education known as blended is a type of teaching and learning that "mixe[s] various event-based activities: self-paced learning, live e-learning, and face-to-face classroom" (Alonso, López, Manrique, \& Viñes, 2005). Effective blended learning is characterized as dynamic (enabling access to experts and high-quality resources online), occurring at real-time, fostering collaboration, personalized, comprehensive (by providing learning events from multiple source, so that learner can select the format most suitable for them) and enabling learning communities (Alonso et al., 2005). The theme of student perceptions, attitudes and preferences for blended learning emerges as the second most researched topic (first being instructional design) in the recent systematic review of blended learning literature (Halverson, Graham, Spring, Drysdale, \& Henrie, 2014); the same study also finding that in general students tend to report high levels of satisfaction with blended learning and express preference for this type of learning over others.

Other studies of blended learning further confirm that overall students are in favor of this learning model because they perceive it useful for their study (Khine \& Lourdusamy, 2003). Recent research (Owston, York, \& Murtha, 2013) comparing student perceptions of blended learning courses (as measured across such metrics as satisfaction, convenience, engagement and achievement of learning outcomes) with their actual achievement (final course grade) found that 
there was a very strong relationship between perception and grade: high achievers were the most satisfied, stating they would study in the blended mode again, their preference for the blended format over fully face-to-face or fully online modes clearly articulated. The study's conclusion that low-achieving students may not be able to cope with the blended format as well high achievers, hence a choice offered to students, where feasible, between different modes of study, was a key recommendation (Owston et al., 2013). In summary, such factors as flexibility, accessibility, and higher levels of autonomy and self-regulation of learning, as well as the opportunities to have face-to-face encounters in combination with independent study and streamlined feedback provision are among main reasons why students prefer blended learning to fully face-to-face or online education.

\section{Social Media as a Learning Tool}

Social media is a generic, all-encompassing term for a range of digital tools and platforms used for networking, sharing, commenting and collaborating online. Social media platforms are normally located outside of LMS environments but can also be embedded into an institutional LMS or used separately, alongside formal learning platforms.

Among benefits of using social media platforms in education are: accessibility (with over a billion of users of Facebook alone (StatisticBrain, 2013), it is likely that students already have accounts with most social media platforms), immediate dissemination of information, fostering of interaction and collaboration, and flexibility and user-friendliness (Fontana, 2009; Gee, 2004; McCarthy, 2013). However, the 'cons' of social media use for teaching and learning include excessive informational convergence and proximity to entertainment content, meaning students can be distracted when accessing social media for learning and waste valuable study time on entertainment and social networking (Tiryakioglu \& Erzurum, 2011). An ethical implication of using social media for learning is that students are likely already using it for private purposes and may not wish to combine their private and public spaces, where related issues of privacy and security arise (Aayeshah \& Bebawi, 2014; Çoklar, 2012). Finally, the issues of assessment of performance and grading of students' work performed via social media platforms present several challenges (Çoklar, 2012).

Overall, social media tools (such as Facebook and Twitter) can often be found as elements of blended courses, where academics want to foster collaboration and peer interaction by adding, for example, some experiential element to their course. Rewarding student participation in social media activities has been found useful to fostering students' engagement in these elements: for instance, point systems and gamification elements have proven to work to some degree (Fontana, 2009). However, others (McCarthy, 2010, p. 1204) have showed that other factors were more important to student uptake: students who were actively using Facebook for study purposes were more likely to already be using Facebook for social networking. Further, a cohort of first-year undergraduate students in the McCarthy's (2013) study appreciated Facebook as a learning tool because it alleviated such typical first-year challenges as language barriers and shyness. Furthermore, having students interact with each other through Facebook helped them establish early connections which were then fostered during the face-to-face activities of their course. Another recent study (Gilmore, In print) found that students tend to use Facebook as an adjunct to formal LMS discussion board activities and overall report feeling less intimidated and anxious about making inadequate responses by discussing threads with 
their Facebook colleagues first. Gilmore's study is consistent with earlier research by Selwyn (2009) who reported on a pattern where students regularly used Facebook to report and reflect on university experiences, such as lectures or interactions with academic staff. Therefore, student expectations and motivations of the learning experience as a whole together with its various elements need to be taken into account: teachers would be well advised to take note of instances such as those reported by Gilmore (In print) where there is obvious overlap in learning between the digital instructional tool and social media.

In summary, how HE students engage with social media for learning is a complex and contested terrain: social media's educational uses vary and many factors, both intrinsic and extrinsic, influence student engagement. It matters whether social media is embedded organically or used in an ad hoc manner, while such factors as students' previous experiences with social media as well as the value they attach to it generally and specifically within a learning context, all matter a great deal.

\section{Educational Technologies}

As outlined earlier, there is a generally accepted view in the HE sector that certain types of students have a high level of expertise with, and are motivated by technology (Prensky, 2001a), and therefore they should be challenged with innovative and entertaining digital resources (Bauerlein, 2008; Ferdig \& Trammell, 2004). This assumption is informed by the 'digital native' concept, coined by Prensky (2001b, p. 1), to define "native speakers of the digital language of computers, video games and the Internet". According to Prensky, people born after 1980 learn and think differently to previous generations because they are immersed in digital technology while their brains are still developing.

Recent studies, however, have challenged many of the key assumptions underpinning Prensky's (2001a) characterization of the digital native. For example, contrary to the popular belief that digital natives need constant stimulation by technology, some argue that students actually rarely use innovative and creative technological tools, if at all (Thompson, 2013) and that they tend to use technology in a rather narrow way. Another study (O'Connell \& Dyment, 2016) found that students are not as technologically savvy as educators assume: for example, students prefer to use basic technology such as word processing for reflective journal assignments because it is the easiest way to complete the assignment. This observation is confirmed once more (Buckenmeyer, Barczyk, Hixon, Zamojski, \& Tomory, 2016): in this study, the dominant technology-using activities of students include email, searching the internet, researching and social networking, with students generally varying in their use of Web 2.0 tools and the ICT skills. Further, in this study (Buckenmeyer et al., 2016, p. 4), while students felt that technology helped them better engage with learning, they did not consider that it facilitated individualized learning or "thinking outside the box" and were also reluctant to learn how to use new technology tools. The latter was due to their fear that with the unfamiliarity might increase the likelihood of poor outcomes. Such hesitancy to take risks with new technology contradicts the assumption of Prensky's (2001a) digital natives as a generation of creative risk takers who have less fear of failure.

In summary, while in their perception students generally appear to be positive about educational technologies, a multitude of factors influencing this preference remains neither very 
well understood nor documented. While students may be overall in favor of technology and various innovations used in their learning such factors as relevance, accessibility and so on play a critical role in the process of students' engagement with technology (Barr, 2016). As another study (Van Zanten, Somogyi, \& Curro, 2012) confirmed, students' use of educational technologies is strategic and determined by an immediate learning need while Venkatesh, Croteau and Rabah (2014) conclude that in addition to such factors as engaging lectures and self-regulated study strategies, effective use of ICT tools by students for various teaching and learning activities plays a significant role in shaping students' perception of course effectiveness.

\section{Methodology}

\section{Study Design}

Conducted in a mid-sized, urban and technology-intensive Australian university, this study investigates student experiences with and preferences for teaching and learning modes and educational technologies used both in and out of the classroom. A fully anonymous multi-modal online pilot survey was developed to gage students' engagement with educational technologies, online and blended learning and social media used as a learning tool and to identify areas where student demands were not met.

The survey contained 32 questions and was distributed to a randomized sample of students enrolled in various units of study throughout Semester 2, 2014. Student emails were extracted via the institutional LMS and randomized using Excel Rand function. The survey remained open for one month, during which 66 valid responses were recorded. In addition to demographic identifiers, ten Likert-scale questions were posed to gage students' past, present and desired interactions with various types of technology within a HE context.

Considering the modest rate of response, for the purposes of analysis, affirmative responses (Agree and Strongly Agree) and negative responses (Disagree and Strongly Disagree) are combined into 'Agree' and 'Disagree' groups of responses respectively. All percentages are rounded up to the nearest whole. Data reports and summaries of qualitative responses were extracted from the survey's digital platform Opinio and analyzed for trends, and themes. The survey's combination of qualitative and quantitative elements facilitates a mixed-data driven study (Bazeley, 2009) where students' varied experiences with educational technologies are captured in all their complexity. As this is a small-scale pilot study, its findings are to be used to inform larger scope research into student perceptions of educational technologies. With mixed methods approaches having known capacity to increase the reliability and validity of data in small-scale studies (Zohrabi, 2013), our study sought to collect two types of data (quantitative and qualitative), while having both co-authors engage in collaborative data analysis ensured a further triangulation of results.

\section{Sample}

The sample consisted of 66 students. The largest group of student participants (37\%) were in the age bracket of $21-25$, followed by those in the $18-20$ bracket (21\%) and smaller brackets of 31-40 and 26-30 respectively, as well as some students who were over 40 years of age. The 
gender split was close to 50/50. A large group of students in our sample (42\%) were not employed; followed by small segments of the sample of those who worked part-time (6-20 hours a week) and those employed full-time. In regards to the types and modes of student enrolment, $71 \%$ of students in this sample were enrolled on a full-time basis and most $(79 \%)$ were studying an undergraduate degree. Domestic (Australian) students (78\%) dominated the sample over international ones. The largest group in the sample was either in their second $(36 \%)$ or in their third (33\%) year of study. In regards to students' broad discipline/area of study, most students were from sciences and engineering (43\%); followed by those from business and law (37\%), with a small percentage (9\%) from arts and social sciences. Based on their enrollment at the time of this study, most students had all their units offered in a face-to-face mode $(78 \%)$, with a small group of students (just over 6\%) enrolled in either a blended or fully-online mode.

While not large, the sample was reflective of the university's dominant student population in that students were primarily young and only worked part-time while attending lectures fulltime. This allowed for some generalizability of findings, in particular regarding younger, domestic students, studying in the face-to-face on campus mode.

\section{Results}

The study's findings can be divided into three broad thematic groups. The first group reports on student preferences for and engagement with the three main modes of teaching and learning: that is, fully-online, fully face-to-face, and blended. The purpose is to gage how student preferences apply to such aspects of the learning process as comprehension of concepts introduced in lectures, participation in group work and collaboration. The second group of findings offers new insights into how students engage with social media within learning contexts, while the third and final group of findings reports on student preferences for educational technologies as defined by various factors.

\section{Teaching and Learning Delivery Modes}

While, the majority of students in this study were primarily enrolled in fully face-to-face units, most student participants declared a strong preference for the blended mode of study, when compared to both fully face-to-face and fully online modes. Over half of student participants (56\%) valued blended learning for the flexibility it afforded while $78 \%$ credited it improved comprehension of concepts.

In regards to the collaborative work, students expressed a slight preference for face-to-face study groups over online group work enabled either via LMS or non-LMS tools, such as social media (Facebook) and Google Hangouts (Table 1). An open-ended comment left by a student specified that as long as the content was clear and structured, they had "no issues with the methods [of delivery] used" implying that they could learn in and adapt to various methods of delivery if it was well designed and laid out. 
Table 1. Student Preferences for Education Delivery Mode

\begin{tabular}{|l|l|l|l|}
\hline \multicolumn{1}{|c|}{ Mode of education delivery } \\
\hline \multicolumn{1}{|c|}{ Agree } & \multicolumn{1}{|c|}{ Disagree } & \multicolumn{1}{|c|}{ Neutral } \\
\hline $\begin{array}{l}\text { I prefer a combination of online and face-to- } \\
\text { face (in-class) learning over only face-to-face } \\
\text { learning }\end{array}$ & $46 \%$ & $25 \%$ & $22 \%$ \\
\hline $\begin{array}{l}\text { I prefer a combination of online and face-to- } \\
\text { face learning over only-online learning }\end{array}$ & $67 \%$ & $11 \%$ & $14 \%$ \\
\hline $\begin{array}{l}\text { The ability to study in a blended mode (both } \\
\text { online and in-class) helps me understand } \\
\text { concepts better }\end{array}$ & $78 \%$ & $5 \%$ & $17 \%$ \\
\hline I like the flexibility of a blended course Group work & $56 \%$ & $17 \%$ & $19 \%$ \\
\hline $\begin{array}{l}\text { I prefer to participate in online study groups } \\
\text { with other students }\end{array}$ & $30 \%$ & $44 \%$ & $19 \%$ \\
\hline $\begin{array}{l}\text { I prefer to participate in face-to-face study } \\
\text { groups with other students }\end{array}$ & $49 \%$ & $25 \%$ & $18 \%$ \\
\hline
\end{tabular}

\section{Social Media for Learning}

A significant result in regards to social media used as a learning tool was the number of students who reported using social media for communication purposes, when communicating with their fellow students, but not with their instructors. With $49 \%$ of student participants agreeing that they use social media to communicate with their classmates in regards to their study, only $3 \%$ agreed that this was true in regards to communicating with their instructors. Based on an additional write-in question asking what educational technology students used for learning related purposes, they also named online chats and email. One expressed an interest in the availability of a "university special" mobile phone app for "connecting classmate to share their questions." This student made the interesting observation that while it was easy to communicate with a classmate using social media/technologies it was "difficult to ask lecturer [questions] online." This is consistent, for example, with conclusions drawn by Kennedy, Judd et al. (2008) who also observed that most students use technology only for communication, rather than in innovative and creative ways.

Table 2: Students' Use of Social Media for Learning

\begin{tabular}{|l|l|l|l|}
\hline Statement & Agree & Disagree & Neutral \\
\hline $\begin{array}{l}\text { I use social media (Twitter, Facebook, etc.) } \\
\text { to communicate with other students about } \\
\text { my studies }\end{array}$ & $49 \%$ & $25 \%$ & $18 \%$ \\
\hline $\begin{array}{l}\text { I use social media (Twitter, Facebook, etc.) } \\
\text { to communicate with my instructors about } \\
\text { my studies }\end{array}$ & $3 \%$ & $74 \%$ & $15 \%$ \\
\hline
\end{tabular}




\section{Educational Technologies}

In an open-end question, students were asked to share their views about educational technologies currently available to them and those desired for more effective learning. Five major themes were identified based on student responses, with improved accessibility and the quality of technologies being a recurring motif. The themes are presented next in the order of the most mentioned to the least mentioned.

\section{Improved Accessibility}

Students have expressed a general need for better accessibility made possible with educational technologies. Among practical tools students named as useful for this purpose were e-books/etexts, electronic writing pads to be used by lecturers (such as Wacom), live broadcasts of lectures (as well as audio-only lectures, and an option to play lecture-recordings offline), online study spaces with rovers who can provide assistance on request, live online chats accommodating different student schedules and, finally, a mobile phone application allowing students to connect with classmates based on their unit code.

\section{Improved Quality}

Students expressed a need for the overall improved quality of technology offerings. Under this heading were named such tools as lecture-recordings, where students wished for improved sound and better inclusivity of recordings made possible by including in-class demonstrations into video recordings, ensuring compatibilities across all devices. Students also expressed a view that the institutional LMS could be streamlined by stepping away from its java requirements and using flash based collaboration instead.

\section{No Need for Charge}

A small but significant segment of responses reflected an attitude that all current needs in regards to technology were already being met.

\section{Improved Consistency}

Students expressed the need to have access to automated lecture-recording for all subjects, without exception. Also, some expressed a need to have access to lecture summaries/revisions delivered via Dropbox, hence making existing programs more learner-friendly.

\section{Better Alignment of Face-to-face and Online Content}

It was clear overall that students saw value in technology but it did not eliminate their need for having access to face-to-face content. There were students who felt that social media was 
"detrimental to [their] education" as the preference was to learn and collaborate face-to-face; while some wished for more technology-enabled learning tools to be available to them, such as self-test online quizzes for assessment and revision - this way, students felt, they could identify the areas of concerns and gaps and improve their academic performance. Students also wanted to have more links to additional video content of relevance to the topic (like topical documentaries or lectures from other universities).

\section{Conclusions}

This study found that students had a strong preference for a blended mode of learning over a traditional face-to-face format or a fully-online study; their preference was determined by the flexibility afforded by the blended delivery as well a perception that studying in a blended mode improved their comprehension of material. In regards to group work, most students preferred to collaborate with their peers in the face-to-face settings rather than online. Where social media use for learning is concerned, nearly half of students stated they use social media to communicate with their peers about their studies, while almost no students used social media to communicate with their instructors. Finally, most student participants reported that their needs were met by the technology presently available to them, and that as long as we as an institution "keep aiming to improve [technology], [students will be] happy." Specific suggestions made by student participants for improving technology tended to center around basic upgrades such as higher definition video and audio recordings; faster Wi-Fi download times; more access to storage spaces such as Dropbox; greater compatibility with diverse electronic devices and increased digital capabilities in lecture rooms, such as lecture-recordings available for all units without exception.

This study's findings resonated well with other recent research demonstrating that students overall see blended learning positively (Khine \& Lourdusamy, 2003; Owston et al., 2013), crediting it with flexibility and accessibility among other study-friendly features. Our findings concerned with social media are also reflective of prior research (Aayeshah \& Bebawi, 2014) which showed that students are likely to utilize social media for peer networking rather than for learning purposes. The most interesting findings, however, emerge in regards to students' use of educational technologies. These are consistent with results of other studies arguing that students generally use technology in a narrow way, rarely engaging with technological tools, unless it is presented to them as something integral to their learning or if they are already familiar with a particular tool and/or perceive a tool as useful and not a waste of time (Thompson, 2013). Our findings also concur with those of the Henderson et al.'s (2015) study exploring the nature of students' digital practices which found that students used educational technologies strategically, their engagement determined by learning needs. In our study, for example, two requests regarding more innovative technology included one for "online quizzes for assessment revision," and another for teachers to interact more with Smartboards which were apparently not usually activated in equipped classrooms.

Despite a well cited characteristic by proponents of digital natives that these students need constant entertainment (Bauerlein, 2008; Prensky, 2001a), our study found no evidence that this was the case. Students commented on the program structure as well as content, with one participant criticizing the university's LMS as "clunky with its java requirement and usability." Another participant felt a weekly face-to-face lecture was necessary "so we can understand the 
concept of the work instead of email and posting on Group discussion board." It was interesting that this student prioritized the need for an additional (presumably, face-to-face) lecture over a wider choice of technology. There was, however, no suggestion that students considered teachers to be failing in their duty to them with the technology-rich teaching environment which, according to the digital native debate, they clearly need (Bauerlein, 2008; Rideout et al., 2010; Rosen \& Beck-Hill, 2012; Tapscott, 2009). On the contrary, one student was unhappy that their teacher had experimented with Facebook instead of offering only the traditional face-toface lecture, complaining that "it caused me to not attend or participate and found it was detrimental to my education." As Thompson (2013) states, it does appear that although students expect teachers to use technology and present content in an engaging manner, they are willing to learn in a situation that is not always entertaining. Furthermore, students of this generation are not necessarily willing to take risks with new or unfamiliar technology unless they are convinced of its positive benefits in educational outcomes. It is clear that an answer to the question as to how and why students engage with and use technology is a highly complex one and that further research is needed in this area.

\section{Recommendations}

Based on this study, our recommendations for more impactful technology-enhanced teaching and learning practice include:

- The process of adding technology-enhanced elements into face-to-face courses has to be mindful and organic, with all elements of the resulting blended course carefully considered and complementing one another. As students see a great value in learning flexibility afforded by blended courses, such courses must offer useful technologies to help students learn at their own time and pace. Such technologies also need to be value-added and appropriate to students' learning outcomes.

- If academics wish to use social media elements in their teaching, they need to be aware of how students engage with social media and what their expectations are. Professional development of academics therefore would need to include social media and general technology training to ensure their familiarity with it, leading to a thoughtful conceptual design and practical implementation. This is particularly significant in regard to students' identity and privacy issues as well as the trend to supplement - or at times substitute - social media for technology embedded into the LMS.

- On the institutional level, universities urgently need to invest more adequate funding into basic infrastructure, take note of student concerns and ensure timely upgrades to existing technology and hence its seamless use.

\section{References}

Aayeshah, W. \& Bebawi, S. (2014). The Use of Facebook as a Pedagogical Platform for Developing Investigative Journalism Skills. In G. Mallia (Ed.), The social classroom: integrating social network use in education (pp. 83-99). Hershey, PA: IGI Global. 
Alonso, F., López, G., Manrique, D., \& Viñes, J. M. (2005). An instructional model for web-based e-learning education wtih a blended learning process approach. British Journal of Educational Technology, 36(2), 217-236. doi:10.1111/j.1467-8535.2005.00454.x

Barr, D. (2016). Students and ICT: An analysis of student reaction to the use of computer technology in language learning. IALLT Journal of Language Learning Technologies, 36(2), 19-38.

Bauerlein, M. (2008). The dumbest generation: How the digital age stupefies young Americans and jeopardizes our future (or, don't trust anyone under 30). London, England: Penguin.

Bazeley, P. (2009). Editorial: Integrating data analyses in mixed methods research. Journal of Mixed Methods Research, 3(3), 203-207.

Buckenmeyer, J., Barczyk, C., Hixon, E., Zamojski, H., \& Tomory, A. (2016). Technology's role in learning at a commuter campus: The student perspective. Journal of Further and Higher Education, 40(3), 412-431. doi: 10.1080/0309877X.2014.984596

Coklar, A. N. (2012). Evaluations of students on facebook as an educational environment. Turkish Online Journal of Qualitative Inquiry, 3(2), 42-53.

Ferdig, R. E. \& Trammell, K. D. (2004). Content delivery in the'Blogosphere'. THE Journal (Technological Horizons In Education), 31(7), 12.

Fontana, A. (2009). The multichronic classroom: Creating an engaging environment for all students. Journal for Foundations in Art: Theory and Education, FATE in Review, 30, 1217.

Gee, J. (2004). Situated language and learning: A critique of traditional schooling. New York, NY: Routledge.

Gilmore, D. (in print). A dramaturgical perspective of online university students: A case study of a second year psychology subject. Computers in Human Education.

Guo, Z., Cheung, K., \& Tan, F. (2008). Motivations for using CMC and non-CMC media in learning contexts: A uses and gratifications approach., Proceedings of the ICIC (pp 1-19). Retrieved on 1 December 2016 from http://aisle.aisnet.org/icis2008.

Gurung, B. \& Rutledge, D. (2014). Digital learners and the overlapping of their personal and educational digital engagement. Computers \& Education, 77, 91-100. doi:http://dx.doi.org/10.1016/j.compedu.2014.04.012

Halverson, L. R., Graham, C. R., Spring, K. J., Drysdale, J. S., \& Henrie, C. R. (2014). A thematic analysis of the most highly cited scholarship in the first decade of blended learning research. The Internet and Higher Education, 20, 20-34. doi:http://dx.doi.org/10.1016/ j.iheduc.2013.09.004

Helsper, E. J. \& Eynon, R. (2010). Digital natives: where is the evidence? British Educational Research Journal, 36(3), 503-520. doi:10.1080/01411920902989227

Henderson, M., Selwyn, N., Finger, G., \& Aston, R. (2015). Students' everyday engagement with digital technology in university: exploring patterns of use and 'usefulness'. Journal of Higher Education Policy and Management. doi: 10.1080/1360080X.2015.1034424

Hoffman, M. E. \& Vance, D. R. (2005). Computer literacy: what students know and from whom they learned it. ACM SIGCSE Bulletin, 37(1), 356-360. 
Johnson, L., Adams Becker, S., Estrada, V., \& Freeman, A. (2015). NMC Horizon report: Higher education edition. The New Media Consortium. Retrieved 20 November 2016 from http://cdn.nmc.org/media/2015-nmc-horizon-report-HE-EN.pdf.

Jones, C., Ramanau, R., Cross, S., \& Healing, G. (2010). Net generation or Digital Natives: Is there a distinct new generation entering university? Computers and Education, 54(3), 722-732. doi:10.1016/j.compedu.2009.09.022

Kennedy, G., Dalgarno, B., Bennett, S., Judd, T., Gray, K., \& Chang, R. (2008). mmigrants and natives: investigating differences between staff and students' use of technology. In R. Atkinson \& C. McBeath (Eds.), Annual Conference of the Australasian Society for Computers in Learning in Tertiary Education (pp. 484-492). Melbourne, Australia: Deakin University.

Kennedy, G., Judd, T., Churchward, A., Gray, K., \& Krause, K.-L. (2008). First year students' experiences with technology: Are they really digital natives. Australasian Journal of Educational Technology, 24(1), 108-122. doi:http://dx.doi.org/10.14742/ajet.1233

Khine, M. S. \& Lourdusamy, A. (2003). Blended learning approach in teacher education: combining face-to-face instruction, multimedia viewing and online discussion. British Journal of Educational Technology, 34(5), 671-675. doi:10.1046/j.00071013.2003.00360.x

Kukulska-Hulme, A. (2012). How should the higher education workforce adapt to advancements in technology for teaching and learning? The Internet and Higher Education, 15(4), 247-254. doi:http://dx.doi.org/10.1016/j.iheduc.2011.12.002

Kvavik, R. B. (2005). Convenience, communications, and control: How students use technology. Educating the net generation, 1, 7.1-7.20.

Margaryan, A., Littlejohn, A., \& Vojt, G. (2011). Are digital natives a myth or reality?: University students' use of digital technologies. Computers \& Education, 56(2), 429-440. doi:10.1016/j.compedu.2010.09.004

McCarthy, J. (2010). Blended learning environments: Using social networking sites to enhance the first year experience. Australasian Journal of Educational Technology, 26(6), 729740. doi:http://dx.doi.org/10.14742/ajet.1039

McCarthy, J. (2013). Learning in Facebook: First year tertiary student reflections from 2008 to 2011. Australasian Journal of Educational Technology, 29(3), 337-356. doi:http://dx.doi.org/10.14742/ajet.373

O'Connell, T. \& Dyment, J. (2016). 'I'm just not that comfortable with technology': Student perceptions of and preferences for Web 2.0 technologies in reflective journals. Journal of Further and Higher Education, 40(3), 392-411. doi:10.1080/0309877X.2014.984594

Owston, R., York, D., \& Murtha, S. (2013). Student perceptions and achievement in a university blended learning strategic initiative. The Internet and Higher Education, 18, 38-46.

Prensky, M. (2001a). Digital natives, digital immigrants part II: Do they really think differently? On the horizon, 9(6), 1-9.

Prensky, M. (2001b). Digital natives, digital immigrants. On the horizon, 9(5), 1-6. 
Rideout, V. J., Foehr, U. G., \& Roberts, D. F. (2010). Generation M [superscript 2]: Media in the Lives of 8-to 18-Year-Olds. Henry J. Kaiser Family Foundation. Retrieved on 9 January 2017 from https://kaiserfamilyfoundation.files.wordpress.com/2013/01/8010.pdf

Rosen, Y. \& Beck-Hill, D. (2012). Intertwining digital content and a one-to-one laptop environment in teaching and learning: Lessons from the time to know program. Journal of Research on Technology in Education, 44(3), 225-241.

Selwyn, N. (2009). Faceworking: exploring students' education-related use of Facebook. Learning, media and technology, 34(2), 157-174. doi:http://dx.doi.org/10.1080/ 17439880902923622

Selwyn, N. (2016). Minding our language: why education and technology is full of bullshit...and what might be done about it. Learning, Media \& Technology, 41(3), 437-443. doi:http://dx.doi.org/10.1080/17439884.2015.1012523

Small, G. \& Vorgan, G. (2008). Meet your iBrain. Scientific American Mind, 19(5), 42-49.

StatisticBrain. (2013). Facebook statistics. Retrieved on 1 December 2016 from http://www.statisticbrain.com/facebook-statistics/

Tapscott, D. (2009). Grown up digital: How the net generation is changing your world. New York, NY: McGraw-Hill.

Teo, T. (2013). An initial development and validation of a Digital Natives Assessment Scale (DNAS). Computers \& Education, 67, 51-57. doi:http://dx.doi.org/10.1016/ j.compedu.2013.02.012

Thompson, P. (2013). The digital natives as learners: Technology use patterns and approaches to learning. Computers \& Education, 65, 12-33. doi:http://dx.doi.org/10.1016/j. compedu.2012.12.022

Tiryakioglu, F. \& Erzurum, F. (2011). Use of social networks as an education tool. Contemporary Educational Technology, 2(2), 135-150.

Van Zanten R., Somogyi, S., \& Curro, G. (2012). Purpose and preference in educational podcasting. British Journal of Educational Technology, 43(1), 130-138. doi:10.1111/j.1467-8535.2010.01153.x

Venkatesh, V., Croteau, A.-M., \& Rabah, J. (2014). Perceptions of effectiveness of instructional uses of technology in higher education in an era of Web 2.0. Paper presented at the 47th Hawaii International Conference on System Sciences, Waikoloa, HI.

Zohrabi, M. (2013). Mixed method research: Instruments, validity, reliability and reporting findings. Theory and Practice in Language Studies, 3(2), 254.

Correspondence: Ekaterina Pechenkina, Ph.D., Research Fellow, Office of the Senior Deputy Vice-Chancellor and Provost for Learning Transformations, Swinburne University of Technology, Hawthorn, Victoria, Australia 